\title{
Cable Television's New Legal Universe: Early Judicial Response to the Cable Act
}

Michael I. Meyerson

University of Baltimore School of Law, mmeyerson@ubalt.edu

Follow this and additional works at: http://scholarworks.law.ubalt.edu/all_fac

Part of the Communications Law Commons, Courts Commons, and the Entertainment, Arts, and Sports Law Commons

\section{Recommended Citation}

Cable Television's New Legal Universe: Early Judicial Response to the Cable Act, 6 Cardozo Arts \& Ent. L.J. 1 (1987)

This Article is brought to you for free and open access by the Faculty Scholarship at ScholarWorks@University of Baltimore School of Law. It has been accepted for inclusion in All Faculty Scholarship by an authorized administrator of ScholarWorks@University of Baltimore School of Law. For more information, please contact snolan@ubalt.edu. 


\title{
CABLE TELEVISION'S NEW LEGAL UNIVERSE: EARLY JUDICIAL RESPONSE TO THE CABLE ACT
}

\author{
Michael I. Meyerson*
}

\section{INTRODUCTION}

On October 29, 1984, a new era began in the relationship between law and cable television. On that day the Cable Communications Policy Act of 1984 (the "Cable Act") was signed into law. ${ }^{1}$

The Cable Act is the first comprehensive federal cable legislation. Prior to its passage, the Federal Communications Commission ("FCC") regulated cable pursuant to its "ancillary" power over broadcasting ${ }^{2}$ through the Communications Act of $1934,{ }^{3}$ which was enacted long before the technology of cable was invented, ${ }^{4}$ and hardly drafted with cable in mind.

Regulatory problems were created by the fact that different levels of government were involved in the regulation of cable. Not only did the FCC have an interest in protecting broadcast television, ${ }^{5}$ state and local governments had an interest in overseeing the cable operator's use of public streets and rights-ofway. "A city needs control over the number of times its citizens must bear the inconvenience of having its streets dug up and the best times for it to occur. Thus, government and cable operators

- Assistant Professor of Law, University of Baltimore. B.A. Hampshire College, 1976; J.D. University of Pennsylvania, 1979.

1 See Cable Communications Policy Act of 1984, Pub. L. No. 98-549, 98 Stat. 2779 (codified at 47 U.S.C. $\$ \S 521-559$ (Supp. III 1985)). Since the legislative history and many courts use the numbering of sections from the original law as passed, this Article will also use that numbering in the text. Footnotes will provide both section numbers where appropriate.

2 See United States v. Southwestern Cable Co., 392 U.S. 157, 178 (1968). But see Capital Cities Cable, Inc. v. Crisp, 467 U.S. 691 (1984) (upholding FCC regulation whose purpose was to ensure that " 'the benefits of cable communications become a reality on a nationwide basis." "Id. at 708, quoting Duplicative and Excessive Over-Regulation-CATV, Report and Order, 54 F.C.C.2d 855, para. 33 at 865 (1975)).

347 U.S.C. $\$ \S 151-610$ (1982 \& Supp. III 1985).

4 In 1948, one of the earliest, if not the first, cable television systems was constructed in Mahanoy City, Pennsylvania, by an appliance store owner who built it to create demand for television sets at his store. S. Weinstein, Getring the Picture (1986).

5 See generally 47 U.S.C. § 303 . The FCC has stated that cable uses "broadcast signals as the backbone of the service they provide." CATV, First Report and Order, 20 F.C.C.2d 201, para. 46 at 222 (1969). 
are tied in a way that government and newspapers are not." 6 The resulting division of regulatory power was described optimistically as "a deliberately structured dualism."' Local governments had primary control over the awarding and terms of franchises,${ }^{8}$ but the FCC supervised areas such as signal carriage ${ }^{9}$ and franchise fees. ${ }^{10}$

By 1984, Congress had concluded that the regulatory mix was unworkable. As described by the lead Senate sponsor of the Cable Act:

Comprehensive legislation is needed to replace the patchwork of Federal, State, and local regulations and court decisions that have been governing cable. The Communications Act, written over 50 years ago before cable even existed, provides little or no guidance. The result has been an unstable regulatory environment that has been bad for the cable industry, bad for the local and State franchising authorities, and bad for consumers. ${ }^{11}$

The Cable Act radically altered the regulatory "patchwork." Virtually every area of cable regulation is covered by the thirty-eight sections of the Cable Act. ${ }^{12}$ For the first time, federal legislation has

6 Community Communications Co. v. City of Boulder, 660 F.2d 1370, 1378 (10th Cir. 1981), cert. dismissed, 456 U.S. 1001 (1982).

7 Cable Television, Report and Order, 36 F.C.C.2d 143, para. 177 at 207 (1972).

8 "Most decisions related to the award of a cable franchise have historically been made at the municipal level." H.R. REP. No. 934, 98th Cong. 2d Sess. 23 reprinted in 1984 U.S. Code, Cong. \& Admin. News 4655 [hereinafter House. RePort].

9 See Capital Cities Cable, Inc., 467 U.S. at 716 (upholding FCC preemption of state regulation of the "signals carried by cable operators."); Quincy Cable TV, Inc. v. FCC, 768 F.2d 1434, 1437 (1985) (striking down FCC "must-carry" requirement that cable operators carry "[e]very over-the-air television broadcast signal that is significantly viewed in the community" "), cert. denied, 106 S. Ct. 2889 (1986); Community Cable TV, Inc., Memorandum Opinion and Order, 95 F.C.C.2d 1204 (1984) (FCC ruling barring franchising authorities from stopping cable operators from removing or realigning programming offered on regulated tiers).

10 FCC Cable Television Service, 47 C.F.R. $\$ 76.31$ (1984) (deleted and removed 1985) (limiting franchise fees to three percent of a cable system's gross revenue per year, subject to an increase to five percent if "appropriate in light of the planned local regulatory program." Implementation of the Provisions of the Cable Communications Policy Act of 1984, 50 Fed. Reg. 18,637, 18,648 (1985) [hereinafter Implementation], aff'd in part. ACLU v. FCC, 823 F.2d 1554 (D.C. Cir. 1987)).

11130 Conc. Rec. S14,283 (daily ed. Oct. 11, 1984) (statement of Sen. Goldwater). The first cable system was constructed in 1948. See D. Brenner \& M. Price, Cable Television and Other Nonbroadcast Video 1-2 (1986). Thus, the Communications Act of 1934 actually preceded the advent of cable television by only 14 years.

12 Cable Act $\$ \S 601-639,47$ U.S.C. $\$ 521-559$ (Supp. III 1985). The Act did not resolve issues regarding the regulation of "non-cable communication services," such as data transmission. House REPORT, supra note 8, at 60 (The Committee on Energy and Commerce "intends that state and Federal authority over non-cable communications services under the status quo shall be unaffected by the provisions of [the Cable Act]."); see also In re Generic Investigation into Cable Television Service in New Mexico, 103 
defined the scope of regulatory power at all levels of government. The local franchising process was termed "the primary means of cable television regulation," 13 subject now to explicit statutory limitation.

As with any major new law, litigation has begun to determine the scope and meaning of the statute. This Article will explore the first judicial attempts to interpret the Cable Act. A common thread running through these varied cases, if any, is the courts' apparent lack of appreciation of the Act's complexity. Many, though not all, decisions appear to misread congressional language and misinterpret congressional intent. Future litigation will inevitably explore these issues more fully and perhaps with a fuller understanding of the regulatory framework Congress attempted to create.

The first part of this Article will discuss issues common to all sections of the Cable Act: the purposes of the Act, retroactivity and grandfathering, and the constitutionality of cable regulation. ${ }^{14}$ The second part will discuss judicial interpretation of specific sections of the Act: rate regulation, modification, tenants' access to cable television and cable piracy.

\section{Understanding the Cable Act}

\section{A. Purposes of the Cable Act}

In interpreting any federal statute, it is critical to determine the intent of Congress in enacting the legislation. "If a court, employing traditional tools of statutory construction, ascertains that Congress had an intention on the precise question at issue, that intention is the law and must be given effect." 15 Even if Congress did not expressly address a particular "precise" issue before a court, questions of the coverage of a statute may still be resolved by an evaluation of "the policy concerns that motivated the enactment."16

When Congress enacted the Cable Act, it attempted to explicitly enumerate the "policy concerns" behind the statute. Ironically, the concerns were so numerous and so complex that

N.M. 345, 707 P.2d 1155 (1985) (state regulation of data transmission services offered by a cable operator are not preempted).

13 House REPORT, supra note 8, at 19.

14 The issue of standing to sue under the Cable Act is addressed in a separate article in this Survey. See Manishin, Antitrust and Regulation in Cable Television: Federal Policy at I'ar with Itself, 6 CARdozo ARTs \& ENT. L.J. 75 (1987).

15 Chevron U.S.A., Inc. v. Natural Resources Defense Council, Inc., 467 U.S. 837, 843 n.9 (1984).

16 Id. at $862-63$. 
the statement of congressional intent has frequently confused the courts, rather than elucidated them.

The first section of the Cable Act, ${ }^{17}$ details six purposes for the legislation:

(1) establish a national policy concerning cable communications;

(2) establish franchise procedures and standards which encourage the growth and development of cable systems and which assure that cable systems are responsive to the needs and interests of the local community;

(3) establish guidelines for the exercise of Federal, State, and local authority with respect to the regulation of cable systems; (4) assure that cable communications provide and are encouraged to provide the widest possible diversity of information sources and services to the public;

(5) establish an orderly process for franchise renewal which protects cable operators against unfair denials of renewal where the operator's past performance and proposal for future performance meet the standards established by this subchapter; and

(6) promote competition in cable communications and minimize unnecessary regulation that would impose an undue economic burden on cable systems. ${ }^{18}$

This list reflects the intricate compromise hammered out by Congress. ${ }^{19}$ The purposes of the Cable Act are many, and occasionally border on being contradictory, because Congress was attempting to balance conflicting interests of the regulators (the franchising authorities), the regulated (the cable companies), and the public. ${ }^{20}$

Nonetheless, several early interpretations of congressional purpose have missed the full scope of interests that Congress was trying to accommodate. The clearest misstatement was made by the FCC in its primary Rule Making on the Cable Act. ${ }^{21}$ After stating that "in

17 The major sections of the Cable Act that are not in Title Six involve pole attachments, sec. 4 (amending Title Two); unauthorized reception of satellite programming, sec. 5 (Title Seven); the Telecommunications Policy Study Commission, sec. 8 (Title Seven).

18 Cable Act $\$ 601,47$ U.S.C. $\$ 521$ (Supp. III 1985).

19 In the words of the lead sponsor of the Cable Act in the House of Representatives: "This legislation has not been put together hastily; it is a carefully crafted set of compromises that has emerged from over 3 years of hearings, discussions, and negotiations by members of the Committee on Energy and Commerce, and representatives of the cities, the cable industry, and many others." 130 ConG. REc. H10,435 (daily ed. Oct. 1, 1984) (statement of Rep. Wirth).

20 See 130 Cong. Rec. S14,283 (daily ed. Oct. 11, 1984) (statement of Sen. Goldwater) (The Cable Act is "proconsumer, procity, and procable.").

21 See Implementation, supra note 10. 
adopting appropriate regulatory standards we must keep in mind the underlying purposes of the Cable Act," 22 the FCC described, with selective quotations, the goals of the Cable Act as stated in the Act itself:

Foremost among these [purposes] is the intent of the statute to establish "standards which encourage the growth and development of cable systems . .. assure that cable communications provide ... the widest possible diversity of information sources and services to the public" and "promote competition in cable communications and minimize unnecessary regulation that would impose an undue economic burden on cable systems."23

This condensation of congressional purpose supports the FCC's view that the primary intent of Congress was to "significantly deregulate the provision of cable service." 24 A deleted phrase of the statutory purpose, however, expresses congressional support for franchise standards and procedures "which assure that cable systems are responsive to the needs and interests of the local community."25 The complete statutory language indicates that Congress was as concerned with guaranteeing the continuation of necessary regulatory oversight of cable systems, as it was with removing unnecessary regulation. The court that reviewed the FCC's rulemaking recognized that Congress was attempting to strike a balance between these interests. "In establishing regulatory guidelines, Congress was concerned both with relieving the cable industry from unnecessary, burdensome regulation and with ensuring that cable systems remain responsive to the needs of the public."26

Several courts have been as myopic as the FCC, however, in describing congressional intent. For instance, one narrow question was whether the automatic five percent annual rate increase, available to cable operators whose rates were regulated, ${ }^{27}$ could be taken twice within a few months if the months were in different calendar years. One court relied on "Congress' unmistakable intent to limit governmental rate regulation in favor of marketplace competi-

22 Id. at 18,652 .

23 Id. at $18,652-53$.

24 Id. at 18,650 n. 69 .

25 Cable Act $\S 601(2), 47$ U.S.C. $\$ 521(2)$ (Supp. III 1985) (emphasis added).

26 ACLU v. FCC, 823 F.2d 1554, 1559 (D.C. Cir. 1987) (emphasis in original). In fact, the court appeared to chide the FCC for its one-sided interpretation. While reversing an FCC decision limiting the "tiers" of programming subject to rate regulation, the court stated that, "the Commission invokes what it perceives to be the general deregulatory focus of the Act." Id. slip op. at 33.

27 See infra note 149 and accompanying text. 
tion."28 This statement of purpose was irrelevant to the issue before the court, since the problem before the court covered rates which Congress had determined could be regulated. Moreover, Congress did indeed believe that, in localities where true competition exists, rate regulation was unnecessary. ${ }^{29}$ Congress also stated that such regulation was still needed, and thus would be permitted wherever cable systems were not subject to effective competition. ${ }^{30}$ This court did not address this countervailing interest.

In Tribune-United Cable of Montgomery County v. Montgomery County, ${ }^{31}$ the Fourth Circuit considered whether a franchising authority had the power to penalize a cable operator for violations of a franchise provision after the operator had sought to obtain modification of that provision. ${ }^{32}$ The court gave a subtle reemphasis of Congressional intent:

The purposes and thrust of the Act, however, evince a congressional desire that franchise agreements be applied and modified so as to obtain a realistic and flexible regulatory framework recognizing the needs of both local governments and cable operators, but primarily concerned with providing viable cable systems responsive to the needs and interests of the local communities they serve. ${ }^{33}$

The Fourth Circuit omitted from its description of intent, the statutory language expressing the congressional desire that franchising procedures "assure" the responsiveness of cable systems to the needs and interests of their communities. ${ }^{34}$ By overlooking the word "assure," the court appeared to devalue the role Congress intended for local regulatory control. ${ }^{35}$ Instead, the court

28 Town of Barnstable v.TCI-TAFT Cablevision Assoc., No. 86-0143 slip op. (D. Mass. May 13, 1986) (LEXIS, Genfed library, Dist File). See infra note 149 and accompanying text.

29 "[T]he availability of competing sources of programming in a given market will keep the rates for basic cable services reasonable in that market without the need for regulation." HOUSE REPORT, supra note 8 , at 25. For a discussion of the rate deregulation provision, Cable Act $\S 623,47$ U.S.C. $\S 543$ (Supp. III 1985), see notes $127-79$ and accompanying text.

30 House REPORT, supra note 8 , at 25.

31784 F.2d 1227 (4th Cir. 1986).

32 Cable Act $\S 625,47$ U.S.C. $§ 545$ (Supp. III 1985); see infra notes $179-95$ and accompanying text.

33 Tribune-United Cable, 784 F.2d at 1231 (emphasis added).

34 Cable Act $\$ 601(2), 47$ U.S.C. \$ 521 (2) (Supp. III 1985).

35 The legislative history stresses congressional "reliance on the local franchising process as the primary means of cable television regulation, while defining and limiting the authority that a franchising authority may exercise through the franchise process." House Report, suprn note 8, at 19; see Rollins Cablevue, Inc. v. Saienni Enter., 633 F. Supp. 1315, 1318 (D. Del. 1986) (describing one of the purposes of the Cable Act as making "the local franchising process the primary means of cable television regulation"). 
erroneously implied a congressional determination that an economically "viable" system will be "responsive" to the community. ${ }^{36}$

The court in Housatonic Cable Vision Co. v. Department of Public Utility Control, ${ }^{37}$ produced a more sophisticated and more accurate analysis of congressional intent. That court concluded that Congress obviously had not intended to preempt all local regulation, ${ }^{38}$ but instead had chosen, "to create a finely-tuned system coordinating federal, state, and local authority and also to preserve those provisions of existing franchises that were not inconsistent with the Cable Act."39

Therefore, the question on any given issue of cable regulation remains as to what level of government Congress granted authority. The court in Housatonic Cable Vision held that a local regulation would be struck down if it would "frustrate the effectiveness of the Cable Act," ${ }^{40}$ but will be valid if it is "not expressly prohibited and can coexist with the Cable Act." 41 Congress established a presumption that most regulatory power would reside at the local level, ${ }^{42}$ but intended that the courts should decide to what extent local power had been limited. In City of New York v. FCC, ${ }^{43}$ the court erroneously stated that Congress intended to "balance" the regulatory jurisdiction of local authorities with that of the FCC: "The Cable Act sought to balance two conflicting goals: 'preserv[ing] the critical role of municipal governments in the franchise process,' ... while affirming the FCC's 'exclusive jurisdiction over cable service, and overall facilities which relate to such service . . ." "44 There are two errors in this analysis. First, unlike the description of the "critical role" of local governments, the statement in the House Report discussing the FCC's role does not come from the congressional statement of

36 Tribune-United Cable, 784 F.2d at 1231.

37622 F. Supp. 798 (D. Conn. 1985).

38 See, e.g., Cable Act $\$ 636$ (b), 47 U.S.C. $\$ 556$ (b) (Supp. III 1985) ("Nothing in this subchapter shall be construed to restrict a State from exercising jurisdiction with regard to cable services consistent with this subchapter."); see also supra note 20.

39 Housatonic Cable Vision, 622 F. Supp. at 812 . The court refers to this balance as a "combination of preemption and preservation." Id. at 802. The court also concluded that one of the underlying purposes of the Cable Act was "to maximize the availability and diversity of cable service." Id. at 811 ; accord Rollins Cablevue, Inc., 633 F. Supp. at 1318.

40 Housatonic Cable Vision, 622 F. Supp. at 806 (citing Perez v. Campbell, 402 U.S. 637. $652(1971))$.

41 Id.

42 See House REPORT, supra note 8, at 24 ("[C]ity officials have the best understanding of local communications needs ...."); see also supra text accompanying note 25.

43814 F.2d 720 (D.C. Cir. 1987) (upholding most FCC preemption of local regulation of technical standards).

44 Id. at 723 (citing House RePORT, supra note 8, at 19,95) (citations omitted). 
the goals of the Cable Act, ${ }^{45}$ but the Report's "Section-By-Section Analysis." Moreover, the court omitted a key phrase from the House Report; the actual sentence referring to the FCC's jurisdiction reads, "Subsection (a)(1) grants the FCC exclusive jurisdiction over cable service ... and over the facilities which relate to such service, as provided in Title VI [the Cable Act]." 46 Thus, instead of issuing a broad policy statement in favor of FCC preemption, Congress did the reverse and limited the powers of the FCC to those specifically enumerated in the Cable Act. The court also erred in concluding that Congress intended the Cable Act to endorse the policies of the FCC that predated the Act: "Since Congress legislated against the backdrop of the Commission's preexisting preemption regulation without criticizing that regulation, we infer that Congress endorsed it, except where the Cable Act explicitly or implicitly modified its provisions." 47 This reasoning is faulty since Congress was dissatisfied with the regulatory structure that was in existence and, in particular, with the FCC. ${ }^{48}$ In describing the necessity for federal statutory guidelines, Congress stated that local franchising would, "be based on certain important uniform Federal standards that are not continually altered by Federal, state or local regulation." 49 Congress intended that the true balance be struck between the statutory limitations imposed by the Cable Act and the remaining powers of local franchising authorities.

Where to strike this balance will not always be obvious. A careful reading of the purposes should inform courts that Congress did not intend for there to be simple answers. The Cable Act is "a carefully crafted set of compromises," 50 balancing competing and conflicting interests. The difficult task assigned to the judiciary is to ensure the maintenance of that precarious balance sought by Congress, i.e., to "[protect] the interests of not only the cities and the cable industry, but those of the consumers of cable services as

45 House Report, supra note 8, at 19-23, 40.

46 Id. at 95 (emphasis added).

47 City of New York v. FCC, 814 F.2d at 725 (emphasis added).

48 As Judge Mikva argued in his dissent, Congress concluded that "[e]xisting regulatory schemes, conceived in cable's infancy or before, were inadequate to the burgeoning industry. Since Congress was constructing from the ground up, it is incongruous to presume it intended to preserve all elements of the previous makeshift approach unless it specifically disclaimed them." Id. at 730 (Mikva, J., dissenting in part).

49 House Report, supra note 8, at 24. See also 130 Cong. REc. H10,444 (daily ed. Oct. 1, 1984) (statement of Rep. Markey) ("[I]f the House fails to pass a Federal cable policy, then our cities will be robbed of their control over cable TV. The era of deregulation, affirmed by the FCC and the Supreme Court, has hit cable regulation with a crippling force.").

50130 Cong. Rec. H10,435 (daily ed. Oct. 1, 1984) (statement of Rep. Wirth). 
well.",51

\section{B. Retroactivity and Grandfathering}

Cable television has been subject to local governmental regulation since its inception, more than three decades before the Cable Act. ${ }^{52}$ While the Act explicitly governs franchises awarded or renewed after the Act's effective date, ${ }^{53}$ a different analysis is needed to determine the validity of laws, regulations, and franchise agreements that predate the Act. There are two related issues: 1) whether the provisions of the Act are to apply retroactively; and 2) whether prior regulatory obligation is continued in effect by the Act's "grandfather" provisions.

In Yakima Valley Cablevision, Inc. v. FCC ${ }^{54}$ the court held that the Cable Act's provision invalidating the FCC's regulation of the amount of franchise fees ${ }^{55}$ did not apply to franchise fee disputes that arose prior to the effective date of the Act. ${ }^{56}$ This ruling is entirely in keeping with the "venerable rule of statutory interpretation ... that statutes affecting substantive rights and liabilities are presumed to have only prospective effect.'

As noted in Yakima Valley Cablevision, ${ }^{58}$ the Cable Act itself provides for a prospective effective date "[e]xcept where otherwise expressly provided, the provisions of this Act and the amendments made thereby shall take effect 60 days after the date of enactment of this Act." 59

The existence of a prospective effective date strongly sug-

51130 Cong. REC. S14,284 (daily ed. Oct. 11, 1984) (statement of Sen. Gorton).

52 House Report, supra note 8, at 23; see also Community Communications Co. v. City of Boulder, 660 F.2d 1370, 1379 (10th Cir. 1981) (describing cable television's tradition of government regulation), cert. dismissed, 456 U.S. 1001 (1982).

53 See, e.g., Cable Act $\$ 624$ (b), 47 U.S.C. $\$ 544$ (Supp. III 1985) (delimiting the scope of regulation of cable services, facilities and equipment, "[i]n the case of any franchise granted after the effective date of this subchapter."). The Cable Act became effective December 29, 1984.

54794 F.2d 737 (D.C. Cir. 1986).

55 Cable Act $\$ 622(\mathrm{i}), 47$ U.S.C. $\$ 542$ (i) (Supp. III 1985); see also House REPORT, supra note 8, at 65 ("The current FCC regulations which restrict the use of franchise fee revenues to cable-related uses and permit franchise fees of five percent only if a waiver is granted by the FCC are invalid by the terms of this legislation.").

56 Yakima Valley Cablevision, 794 F.2d at 747.

57 Bennett v. New Jersey, 470 U.S. 632, 639 (1985) (citations omitted).

58 Yakima Valley Cablevision, 794 F.2d at 747.

59 Cable Act $\$ 3,47$ U.S.C. \$ 542(i) (Supp. III 1985); see also House RePORT, supra note 8, at 96 ("The provisions of [the Cable Act] will take effect 60 days after enactment of the act, except where otherwise expressly provided."). The Cable Act establishes different effective dates for the provision of lock boxes, Cable Act $\$ 624(d)(2), 47$ U.S.C. $\S 544(\mathrm{~d})(2)(\mathrm{B})$ (Supp. III 1985) (180 days after the effective date), and preemption of rate regulation, Cable Act $\$ 623$ (c), 47 U.S.C. $\$ 543$ (c) (Supp. III 1985) (local rate regulation permitted for two years from effective date). 
gests that Congress intended to only govern arrangements that followed that date. If Congress had wished to alter rights or obligations arising prior to the passage of the Act, the relevant governing provisions would have been made effective immediately.

The court's finding that the Cable Act is not to be applied retroactively is consistent with both the Act itself and prior court rulings on retroactivity. ${ }^{60}$ The court, however, in its analysis, seems to confuse retroactivity with grandfathering. The fundamental distinction between the two concepts is that a statute with retroactive effect changes rights and liabilities that have accrued prior to its enactment, ${ }^{61}$ while grandfathering continues the force of a law or franchise subsequent to the law's effective date.

The court found one issue for which the Act was intended to have a retroactive effect: "Congress intended to make only one narrow exception to the prospective effect of the Cable Act's franchise-fee provisions." 62 .That "exception" provides that a franchise provision requiring a five percent franchise fee is valid without FCC approval, ${ }^{63}$ even though prior to the Cable Act FCC permission was necessary before a fee greater than three percent could be assessed. ${ }^{64}$ To prove the retroactive nature of this provision, the court quoted from the Conference Report:

Any franchise in effect on the effect [sic] date of [the Cable Act] that provides for a franchise fee in an amount up to or in excess of the five percent limitation in section 622 (b) (with or without the need for action by any Federal agency) shall be deemed to have lawfully required such fee, up to but not in excess of five percent, as of such effective date, except that where a franchise explicity [sic] establishes a later date or any condition for the imposition of such fee, such later date or condition shall apply. ${ }^{65}$

The court incorrectly concluded that the language in the Conference Report, "makes it clear that any payments of franchise fees already [i.e., prior to the Act] made by a cable system up to five percent would be lawful without FCC permission if the franchise agree-

60 See Bennett v. New Jersey, 470 U.S. 632 (1985); Bradley v. Richmond School Bd., 416 U.S. 696 (1974); Eikenberry v. Callahan, 653 F.2d 632 (D.C. Cir. 1981); Hastings v. Earth Satellite Corp., 628 F.2d 85 (D.C. Cir.), cert. denied, 449 U.S. 905 (1980).

61 Yakima Valley Cablevision, 794 F.2d at 745-46.

(i2 Id. at 747 .

63 Cable Act $\S 622$ (b) , 47 U.S.C. $\$$ 542(b) (Supp. III 1985); see also House ReporT, supra note 8, at 64 (The Cable Act grants "the authority to collect franchise fees up to five percent without an FCC waiver.").

(64 47 C.F.R. \& 76.31 (1984) (deleted and removed 1985).

6.5 Vakima Valley Cablevision, 794 F.2d at 747 (quoting 130 Cong. REC. S14,285 (daily ed. Oct. 11,1984$)$ ) (emphasis added). 
ment established such a fee." 66 To the contrary, the provision only applies as of "the effect[ive] date of [the Cable Act]." That is, after December 29, 1984, a franchise provision calling for a five percent fee became enforceable, even without FCC approval. Neither the statutory language nor the legislative history indicate that such a provision was to be considered valid for time periods prior to the effective date.

Thus, the court was in error when it treated the Conference Report as implying a retroactive effect to the provision eliminating the need for FCC approval of five percent franchise fees. Congress did not retroactively make valid a franchise provision that was invalid prior to the Act. Instead, Congress grandfathered the provision so that it would be valid after the effective date of the Act. ${ }^{67}$

There are several other provisions of the Cable Act that grandfather preexisting requirements. The broadest provision preserves in effect, "[t]he provisions of . . . any franchise in effect on the effective date of this subchapter ... subject to the express provisions of this subchapter . . .."68

Other provisions permit regulation provided in pre-Act franchises that would not be allowed for newer franchises. For example, although the Act prevents a franchising authority from enforcing post-Act requirements that a cable operator provide "particular video or other information services" 69 and any service, facility, or equipment not related to the operation of a cable system, ${ }^{70}$ a franchising authority may enforce any franchise requirement for services, facilities, and equipment which was in effect prior to the Act. ${ }^{71}$

66 Id. (emphasis added).

67 The Conference Report contains language that may run counter to this conclusion:

Nothing in section 622 shall authorize any payment toward any such fee . . . [i.e., a franchise fee in an amount up to or in excess of the 5 percent limitation in section 622(b)] for any period prior to the effective date of this title, unless such payment has been made prior to such date to a franchising authority.

130 Cong. Rec. S14,285 (daily ed. Oct. 11, 1984) (emphasis added). The italicized language seems to imply that if a fee payment had been made prior to the Act's effective date, then Cable Act $\$ 622,47$ U.S.C. $\$ 542$ (Supp. III 1985) would authorize such payment. There are two problems with this interpretation. First, it seems to contradict the earlier quoted language beginning the validating effect of section 622 "as of" the Act's effective date. See supra text accompanying note 66 . Second, there is no language in the statute itself stating that it is to have retroactive effect.

68 Cable Act $\S 637$ (a), 47 U.S.C. $\$ 557$ (a) (Supp. III 1985).

69 House RePORT, supra note 8 , at 68 (discussing Cable Act $\S 624(\mathrm{~b}), 47$ U.S.C. \$ 544(b) (Supp. III 1985)).

70 Cable Act $\$ 624(a), 47$ U.S.C. $\$ 544$ (a) (Supp. III 1985).

71 Id. at $\$ 624(\mathrm{c}), 47$ U.S.C. $\$ 544$ (c) (Supp. III 1985). Similarly, all payments by a cable operator for support of public, educational and governmental access, required in a pre-Act franchise, are exempt from the five percent franchise fee ceiling. Id. at $\S 622$ 
The court in Housatonic Cable Vision held that these sections protect obligations imposed, not only in the original franchise as drafted, but as amended by modification, ordinance, or regulation prior to the Act: "The breadth of the Cable Act's definition of franchise, coupled with the legislative history, permits the interpretation that the relationship of the parties as it stood at the time the Act became effective represents the franchise for purposes of the grandfather provisons."72

There is one aspect of this court's discussion which may cause some unnecessary confusion. The court did not discuss section $637(a)(2),{ }^{73}$ which grandfathers, for the duration of franchises that were in effect before the Act, provisions of "any law of any State . . in effect on October 30, 1984, or any regulation promulgated pursuant to such law, which relates to such designation, use or support of such [public educational or governmental access] channel capacity."74

Section $637(a)(1)^{75}$ differs from section 637(a)(2) in important respects. The former subsection applies to franchise provisions, while the latter applies to laws and regulations. The former applies to all areas of cable policy; the latter, only applies to access.

A key distinction between the two sections concerns the ability of government to impose new requirements on an existing franchise. Section $637(a)(1)$ bars the imposition of new franchise terms, after the Act, to currently running franchises. Though section $637(a)(2)$ also bars the application of new statutes to existing franchises, it permits the imposition of new regulations on existing franchises, if the regulation is promulgated under a law that predates the Cable Act. ${ }^{76}$

The controlling statutory language states that "any law ... in

(g)(2)(B), 47 U.S.C. $§ 542$ (g)(2)(B) (Supp. III 1985). For post-Act franchises, only "capital costs" for access facilities are exempted. Id. at $\$ 622(\mathrm{~g})(2)(\mathrm{C}), 47$ U.S.C. $\S 542(\mathrm{~g})(2)(\mathrm{c})$ (Supp. III 1985).

72 Housatonic Cable Vision, 622 F. Supp. at 810 (emphasis added).

7347 U.S.C. § 557(a)(2) (Supp. III 1985).

74 Cable Act $\$ 637$ (a)(2), 47 U.S.C. $\$ 557$ (a)(2) (Supp. III 1985) (emphasis added). This subsection states that the word "State" is to be interpreted "as defined in section 153(v) of this title." Id. The Cable Act contains no section so demarked. Rather, section 602(15), 47 U.S.C. \& 552(15) (Supp. III 1985) defines "State" to mean "any State, or political subdivision, or agency thereof." Presumably, that definition is meant to apply to section 637 (a)(2), 47 U.S.C. $\$ 557$ (a)(2) (Supp. III 1985).

7547 U.S.C. $\$ 557$ (a)(1) (Supp. III 1985).

76 Another interesting difference is that section 637(a)(1), 47 U.S.C. $\$ 557$ (a)(1) (Supp. III 1985) preserves franchises in effect prior to the effective date of the Cable Act (Dec. 29, 1984), while section 637(a)(2), 47 U.S.C. \$ 557(a)(2) (Supp. III 1985) preserves laws in effect on the date of enactment (Oct. 29, 1984). Apparently, Congress was more afraid that onerous laws would be passed by state legislatures during the 60 -day period between enactment and the effective date than that onerous terms would be placed in the negotiated franchise. 
effect on October 30, 1984, or any regulation promulgated pursuant to such law,"77 shall apply for the term of existing franchises. The limiting language "in effect on the date of the enactment" only applies to the word "law." There is no limitation on the word "regulation" except that the regulation be promulgated pursuant to a law in effect when the Act was enacted. ${ }^{78}$ Such limitation could have been easily created if Congress had instead used the language "any law or regulation in effect on the date of enactment of this section."

The legislative history makes clear that this interpretation reflects true congressional intent, and not a mere syntactical error on the part of the drafters of the Cable Act. The Committee Report explains that the words "on the date of enactment" were added to section $637(a)(2)$ for "clarifying that only an existing state law, and any regulation promulgated under such a law, related to public, educational or governmental access, are . . grandfather[ed]."79 Again, the time limitation only applies to the law, not the regulation promulgated pursuant to the timely law. Congress surely would have utilized the simpler phrase, "an existing state law or regulation," had it intended to limit the grandfathering to only access-related regulations in effect when the Act became effective.

Thus, the Housatonic Cable Vision court's conclusion that grandfathering only applies to the relationship between parties "as it stood at the time the Act became effective" 80 is not completely accurate. The conclusion does not apply to the narrow category of regulations, relating to public, educational, or governmental access, which have been promulgated pursuant to laws in effect when the Act became effective. ${ }^{81}$ Such regulations may apply to existing franchises.

77 Id. $\$ 637(\mathrm{a})(2), 47$ U.S.C. $\$ 557(\mathrm{a})(2)$ (Supp. III 1985) (emphasis added).

78 See Meyerson, The Cable Communications Policy Act of 1984: A Balancing Act on the Coaxial Wires, 19 GA. L. REv. 543, 586-87 (1985) ("The presumed logic behind this retroactive application ... . is that once the empowering statute had been enacted, the cable operators were on notice that such access-related requirements could be promulgated.").

79130 Cong. Rec. S14,286 (daily ed. Oct. 11, 1984) (emphasis added).

80 Housatonic Cable Vision, 622 F. Supp. at 810 .

81 This analysis also explains the court's statement that, "[o]nce the Cable Act became effective, the DPUC [Department of Public Utility Control] lost the power to impose new obligations . . . in the middle of a franchise term by adopting regulations and issuing orders." Housatonic Cable Vision, 622 F. Supp. at 809. "Power," as interpreted by the court, refers to the substantive power of a state to prohibit a franchisee from charging contributions in aid of construction to a resident of sparse areas. Id. at 808. Section 637(a)(2), 47 U.S.C. \$ 557(a)(2) (Supp. III 1985) does not apply because the regulation did not relate to public, educational and governmental access. Additionally, it seems the DPUC lost its power because the DPUC had regulated cable "in the same manner as pubic utilities," and section 621 (c), 47 U.S.C. \$ 541 (c) (Supp. III 1985) "expressly abolishes the power of states to regulate cable systems as public utilities." Housatonic Cable Vision, 622 F. Supp. at 809. 


\section{Constitutionality of Cable Regulation}

The operation of a cable television system "plainly implicate[s] First Amendment interests."82 Not surprisingly, many types of cable regulation have been challenged as violative of the first amendment. The United States Supreme Court has heard cases attacking indecency regulation, ${ }^{83}$ exclusive franchises ${ }^{84}$ and mandatory public access. ${ }^{85}$ Lower federal courts have also faced issues on the constitutionality of revocation of franchises, ${ }^{86}$ required carriage of broadcast signals ${ }^{87}$ and franchise fees. ${ }^{88}$

The Supreme Court has yet to speak definitively on the constitutionality of such requirements, and has not yet formulated a standard for evaluating their validity. ${ }^{89}$ The lower court's holding, which struck down cable indecency, was affirmed without opinion, ${ }^{90}$ the public access case was decided on statutory

82 City of Los Angeles v. Preferred Communications, Inc., 476 U.S. 488, 106 S. Ct. 2034, 2037 (1986).

83 Wilkinson v. Jones, 107 S. Ct. 1559 (1987), aff'g, 800 F.2d 989 (10th Cir. 1986), aff'g sub nom. Community Television of Utah v. Wilkinson, 611 F. Supp. 1099 (D. Utah 1985).

84 See Preferred Communications, 106 S. Ct. at 2034, aff'g on different grounds, 754 F.2d 1396 (9th Cir. 1985). The Courts of Appeals have faced the first amendment issue also. See Omega Satellite Prod. v. City of Indianapolis, 694 F.2d 119 (7th Cir. 1982); Community Communications, Inc. v. City of Boulder, 660 F.2d 1370, 1378-80 (10th Cir. 1981), cert. dismissed, 456 U.S. 1001 (1982).

85 Midwest Video Corp. v. FCC, 440 U.S. 689 (1979), aff'g on statutory grounds, 571 F.2d 1025 (8th Cir. 1978). The most recent court case upheld the constitutionality of public access requirements. Berkshire Cablevision of R.I., Inc. v. Burke, 571 F. Supp. 976 (D.R.I. 1983), vacated as moot, 773 F.2d 382 (1st Cir. 1985).

86 See, e.g., Central Telecommunications, Inc. v. TCI Cablevision, Inc., 610 F. Supp. 891, 899-903 (W.D. Mo. 1985), aff'd, 800 F.2d 711 (8th Cir. 1986), cert. denied, 107 S. Ct. 1358 (1987); Tele-Communications of Key West, Inc. v. United States, 757 F.2d 1330, 1338 (D.C. Cir. 1985).

87 Quincy Cable TV, Inc. v. FCC, 768 F.2d 1434 (D.C. Cir. 1985), cert. denied, 106 S. Ct. 2889 (1986).

88 Erie Telecommunications, Inc. v. City of Erie, 659 F. Supp. 580 (W.D. Pa 1987).

89 See Preferred Communications, 106 S. Ct. at 2038-39 (Blackmun, J.,concurring):

In assessing First Amendment claims concerning cable access, [to utility poles] the Court must determine whether the characteristics of cable television make it sufficiently analogous to another medium to warrant application of an already existing standard or whether those characteristics require a new analysis .... [Because the record on the motion to dismiss lacked] factual information about the nature of cable television . . . the Court does not attempt to choose or justify any particular standard.

9o Wilkinson v. Jones, 107 S. Ct. 1559 (1987), aff' $g, 800$ F.2d 989 (10th Cir. 1986), aff'g sub nom. Community Television of Utah v. Wilkinson, 611 F. Supp. 1099 (D. Utah 1985). The lower court relied on three different grounds for striking down the law: (1) preemption by the Cable Act, $611 \mathrm{~F}$. Supp. at 1105 (see infra text accompanying notes 115-123); (2) unconstitutional vagueness, id. at 1117 (stating that defining indecent programming by its "time, place, manner, and context" failed to describe with "narrow specificity" which programs were prohibited); (3) overbreadth, id. at 1106-15 (stating that the only cable programming that could be regulated was that which was obscene under Miller v. California, 413 U.S. 15, 24 (1973); see also infra note 115). Although a summary affirmance constitutes the Court's holding as to the merits of a case, Hicks v. 
grounds ${ }^{91}$ and the franchising case was remanded so that factual questions could be resolved prior to the Court's resolution of the constitutional issue. ${ }^{92}$

In evaluating the constitutionality of cable regulation, courts should recognize that Congress has spoken on many of these issues and should pay particular heed to Congress' reasoning. ${ }^{93}$ In 1973, the Court, when faced with a constitutional challenge to an FCC policy permitting broadcasters to refuse to accept paid advertisements, ${ }^{94}$ noted that Congress had left the question to the FCC. The FCC had concluded that "on balance the undesirable effects . . . would outweigh the asserted benefits."95 Since the balancing of competing rights to free expression in the electronic media was so difficult, the Court stressed that considerable weight should be given to the congressionally created statutory framework:

Balancing the various First Amendment interests involved in the broadcast media and determining what best serves the public's right to be informed is a task of a great delicacy and difficulty....

... [W] hen we face a complex problem with many hard questions and few easy answers we do well to pay careful attention to how the other branches of Government have addressed the same problem. ${ }^{96}$

Certainly not all congressional regulation of the electronic media is per se constitutional. ${ }^{97}$ The point is that courts must acknowl-

Miranda, 422 U.S. 332, 344 (1975), the Court has stressed that a summary affirmance does not affirm the rationale behind a judgment, only the judgment itself. Mandel $v$. Bradley, 432 U.S. 173, 176 (1977). Thus, especially when there is more than one rationale for a holding, it is impossible to tell the reasoning endorsed by the Court. See Mandel, 432 U.S. at 176 (stating that a summary affirmance "should not be understood as breaking new ground but as applying principles established by prior decisions to the particular facts involved"). See also id. at 180 (Brennan, J., concurring) (stating that judges must determine whether a summary disposition "not even arguably [rests] upon some alternative nonconstitutional ground"). Accordingly, the Court's affirmance cannot necessarily be relied upon as a groundbreaking precedent holding all regulation of cable indecency unconstitutional.

91 Midwest Video, 440 U.S. at 709 n.19. The Supreme Court did state that the first amendment issue "is not frivolous." Id.

92 Preferred Communications, 106 S. Ct. at 2038.

93 The proper ultimate resolution of these constitutional questions is beyond the scope of this Article.

94 CBS v. Democratic Nat'l Comm., 412 U.S. 94 (1973).

95 Id. at 122.

96 Id. at 102-03 (emphasis added).

97 E.g. , FCC v. League of Women Voters, 468 U.S. 364 (1984) (striking down ban on editorializing by noncommercial broadcasters who received funding from the Corporation for Public Broadcasting). 
edge and weigh congressional judgment.

This deference is especially appropriate for the issues covered by the Cable Act. The legislative history indicates an extraordinary congressional concern with protecting and enhancing the first amendment rights of the cable operator. ${ }^{98}$ Additionally, the cable industry was intimately involved in the drafting of the regulatory provisions of the Cable Act and supported the Act's passage ${ }^{99}$ Accordingly, courts should recognize that in enacting the Cable Act, Congress, far from ignoring the first amendment rights of cable operators, exhibited great sensitivity to their interest in free expression.

Despite the deference due Congress, many courts analyzing constitutional questions have failed to consider, let alone respect, this careful congressional balancing. For example, in Century Federal, Inc. v. City of Palo Alto, ${ }^{100}$ the court found an exclusive franchising arrangement to be unconstitutional. ${ }^{101}$ The court noted that the Cable Act had indeed been passed and stated that, "[ $t]$ he Act was intended to establish a comprehensive national [cable] policy and envisions a franchising arrangement such as that proposed by the [defendant] Cities .... The constitutionality of that Act is not being directly challenged in this litigation ..." 102 There is no mention of either the Act or the congressional determinations in the rest of the case.

Thus, the court, though striking down an exclusive franchise, did not address the significance of the provision indicating the contrary congressional view. Section $541(\mathrm{a})(1)$ authorizes such franchise arrangements: "A franchising authority may award, in accordance with the provisions of this title, 1 or more franchises within its juris-

98 See e.g., House REPORT, supra note 8, at 26 (Congress "does not believe it is appropriate for government officials to dictate the specific programming to be provided over a cable system, and [the Cable Act] reflects this determination."); id. at 34-35 (an access requirement "does not chill the cable operators' speech"); id. at 69 (The Act "protects the cable operator from being forced to provide specific programming.").

99 The Chair of the House Committee on Energy and Commerce, which had jurisdiction over the Cable Act, described the industry's involvement with the legislation:

I requested the National League of Cities and the U.S. Conference of Mayors to sit at the negotiating table with the National Cable Television Association to work out joint legislative recommendations ... regarding cable legislation. ... After months of difficult negotiations, the parties arrived at a compromise agreement. The bill we are considering today is supported by all of these groups.

130 Cong. Rec. H10,442 (daily ed. Oct. 1, 1984) (statement of Rep. Dingell).

100 648 F. Supp. 1465 (N.D. Cal 1986).

101 The court found insufficient justification for the exclusive franchise and also concluded that cable television should not necessarily receive the same level of first amendment protection applied to the broadcast media. Id. at 1475 .

102 Id. at 1468 n.4 (citation omitted). 
diction." ${ }^{03}$ This language explicitly gives local governments the power to decide on a single franchise: Moreover, Congress explained that the obvious interpretation was also the correct one: "This provision grants to the franchising authority the discretion to determine the number of cable operators to be authorized to provide service in a particular geographic area."104

In another case involving exclusive franchises, the Ninth Circuit appeared to disregard both the plain meaning of the Cable Act and its legislative history in finding the Act consistent with a holding that such franchising was unconstitutional. ${ }^{105}$ The court seemed to limit section $544(a)(1)^{106}$ to merely an authorization for "the government to protect its interest in regulating disruption of public resources through a system of permits or franchises." 107 The court stated that it could not agree "with the suggestion in the legislative history" that cities had the discretion to select the number of operators that would be permitted to wire the community, stating that, "[a] construction of such breadth would be invalid." 108

A court certainly should strive to construe statutes so as to avoid finding them unconstitutional. ${ }^{109}$ Nonetheless, it may not rewrite the statute in conflict with clear legislative language. ${ }^{110}$

More significantly, both these decisions on franchising, as well as several other opinions, ${ }^{11}$ have overlooked the directive of the Supreme Court. ${ }^{12}$ Congress has painstakingly created a regulatory framework which covers regulatory issues including: the granting and renewal of franchises, mandatory third party access, and

103 Cable Act $\$ 621(\mathrm{a})(1), 47$ U.S.C. $\$ 541(\mathrm{a})(1)$ (Supp. III 1985) (emphasis added).

104 House RePORT, supra note 8 , at 59.

105 City of Los Angeles v. Preferred Communications, Inc., 754 F.2d 1396 (9th Cir. 1985), aff'd on different grounds, 476 U.S. 488, 106 S. Ct. 2034, 2037 (1986).

106 Cable Act \& 624(a)(1), 47 U.S.C. \$ 544(a)(1) (Supp. III 1985).

107 Preferred Communications, 754 F.2d at 1411 n.11 (emphasis added).

108 Id.

109 E.g., Hamling v. United States, 418 U.S. 87, 113 (1974).

110 See, e.g., Metromedia, Inc. v. San Diego, 453 U.S. 490 (1981).

111 None of the following opinions discuss the congressional balancing of first amendment rights in the area of cable televison: Quincy Cable TV, Inc. v. FCC, 768 F.2d 1434 (D.C. Cir. 1985) (striking down "must-carry" rules that were grandfathered in Cable Act § 624(f)(2), 47 U.S.C. § 544(f)(2) (Supp. III 1985)), cert. denied, 106 S. Ct. 2889 (1986); Tele-Communications of Key West, Inc. v. United States, 757 F.2d 1330, 1338 (D.C. Cir. 1985) (revocation of franchise raises first amendment issue); Central Telecommunications, Inc. v. TCI Cablevision, Inc., 800 F.2d 711, 713-14 (8th Cir. 1986) (denying cable operator's first amendment claim to continue providing service in franchised area), cert. denied, 107 S. Ct. 1358 (1987). In contrast, the district court in Central Telecommunications stated that, "it is noteworthy that federal law has acknowledged the authority of a local governing body to 'award one or more franchises within its jurisdiction." "610 F. Supp. 891, 899 (W.D. Mo. 1985) (quoting Cable Act § 621 (a)(1), 47 U.S.C. § 541 (a)(1) (Supp. III 1985)).

112 See supra text accompanying note 96. 
franchise fees. ${ }^{113}$ A court confronted with a constitutional challenge to such regulation must pay "careful attention" 114 to the reasoning and determinations of Congress. Even if it ultimately disagrees with Congress, the court must explain why it felt constrained to rule the opposite way.

One district court did utilize the Cable Act in a case involving the constitutionality of state cable regulation, and concluded that the Cable Act preempted state regulation of "indecent" cable programming. ${ }^{115}$ As the court noted, the Cable Act bars states and cities from imposing "requirements regarding the provision or content of cable services, except as expressly provided in this Article." 116 Section $638^{117}$ does preserve the ability of state and local government to regulate "libel, slander, obscenity, incitement, invasions of privacy, false or misleading advertising, or other similar

113 In Erie Telecommunications v. City of Erie, 659 F. Supp. 580 (W.D. Pa. 1987), the court ruled that both franchise fees and public access requirements were constitutional. Interestingly, although the court relied heavily on the Cable Act's access provisions, 47 U.S.C. $§ 531$ (Supp. III 1985), and the strong congressional support for access, HousE REPORT, supra note 8, at 30-36, the court did not discuss the congressional endorsement of franchise fees. 47 U.S.C. $\$ 542$ (Supp. III 1985); HousE REPORT, supra note 8, at 20, 26.

114 CBS v. Democratic Nat'l Committee, 412 U.S. 94, 103 (1973).

115 Community Television of Utah v. Wilkinson, 611 F. Supp. 1099, 1105 (D. Utah 1985), aff'd sub nom. Jones v. Wilkinson, 800 F.2d 989 (10th Cir. 1986), aff'd, $107 \mathrm{~S}$. Ct. 1559 (1987). The district court was affirmed "on the basis of the reasons stated in the opinion." 800 F.2d at 991 . "Indecency" is distinct from, and includes far more elements than, "obscenity." Indecency encompasses "language that describes [or pictures that depict], in terms patently offensive as measured by contemporary community standards ... at times of the day when there is a reasonable risk that children may be in the audience." FCC v. Pacifica Foundation, 438 U.S. 726, 732 (1978) (quoting Pacifica Foundation Station WBAI (FM), 56 F.C.C.2d 94, para. 11 at 98 (1975)). Indecent broadcasts may be barred in the middle of the afternoon. See $i d$. at 750 . Obscenity, which is not protected by the first amendment, is established through a three-part test:

(a) whether "the average person, applying contemporary community standards" would find that the work, taken as whole, appeals to the prurient interest .... (b) whether the work depicts or describes, in a patently offensive way, sexual conduct specifically defined by the applicable state law; and (c) whether the work, taken as a whole, lacks serious literary, artistic, political, or scientific value.

Miller v. California, 413 U.S. 15, 24 (1973) (citations omitted).

It is not clear whether the Cable Act imposes a federal penalty on indecent speech. Cable Act $\$ 639,47$ U.S.C. $\$ 559$ (Supp. III 1985) criminalizes the cablecasting of programs that are "obscene or otherwise unprotected by the Constitution of the United States...." The phrase "otherwise unprotected"was not defined by the statute, and may be interpreted so as not to include indecency. See Meyerson, The Right to Speak, The Right to Hear, and The Right Not to Hear: The Technological Resolution to the Cable/Pornography Debate, 21 U. Mich. J.L. REF. _ (1987). Any attempt by any level of government to ban indecent cable programming was subject to strong constitutional challenge. See supra note 90 for cases discussing this proposistion.

116 Cable Act $\$ 624(f)(1), 47$ U.S.C. \& 544(f)(1) (Supp. III 1985) (emphasis added); see also Cable Act $\$ 636$ (c), 47 U.S.C. $\$ 556$ (c) (Supp. III 1985) (any law "inconsistent with this Chapter shall be deemed to be preempted and superseded").

117 Cable Act $\$ 638,47$ U.S.C. $\$ 558$ (Supp. III 1985). 
laws." 118 To decide if state indecency laws are preserved, therefore, a court must determine whether indecency is "similar" to obscenity and, thus, covered by section 638 .

The district court, in Community Television of Utah, Inc. v. Wilkinson, ${ }^{119}$ noted that, although Congress did not use the term "indecency" in section 638, the word was used in two other sections of the Act: ${ }^{120}$

These explicit indecency provisions strongly imply that Congress deliberately omitted indecency from the list in $\$ 638$. It is unlikely that Congress would accidentally omit indecency from $\S 638$, which defines important areas of federal, state and local power, and remember to include indecency in other sections of the Act. ${ }^{121}$

Although the court concluded that the Act "does not preserve state power to regulate indecency," ${ }^{22}$ it seemed to contradict itself by stating that it needed to rule on the constitutionality of indecency laws because " $[t]$ he final resolution of the pre-emption [sic] question necessarily requires a ruling on the first amendment issue." 123 Indeed, if Congress intended to preempt state indecency regulation, there is no need to explore the constitutional question. Congress is certainly permitted to preempt regulation that would otherwise be permissible. ${ }^{124}$ In this area, such preemption may well represent a manifestation of the express congressional intent to "assure that cable communications provide ... the widest possible diversity of

\footnotetext{
118 Id. (emphasis added).

$119611 \mathrm{~F}$. Supp. at 1102-06.

120 Cable Act $\$ 612(\mathrm{~h}), 47$ U.S.C. $\$ 532(\mathrm{~h})$ (Supp. III 1985) (permitting local regulation of programming on commercial access channels if the programming is "obscene, or is in conflict with community standards in that it is lewd, lascivious, filthy, or indecent") (emphasis added); Cable Act $\$ 624(\mathrm{~d})(2)(\mathrm{A}), 47$ U.S.C. $\$ 544(\mathrm{~d})(2)$ (A) (Supp. III 1985) (requiring signal blocking devices, so-called "lock boxes" to be provided "[i]n order to restrict the viewing of programming which is obscene or indecent") (emphasis added). The "lock box," which allows a viewer to "lock out" certain channels and keep them off the home television screen, was intended by Congress to provide "one means to effectively restrict the availability of [indecent] programming, particularly with respect to
} child viewers. " House REPORT supra note 8, at 70.

121 Community Television of Utah, 611 F. Supp. at 1104 . It could also be argued that, although indecency and obscenity both involve "offensive" depictions of sex, Pacifica Foundation, 438 U.S. at 746 (Stevens, J., plurality), they are certainly dissimilar in the type of material they encompass; "Prurient appeal is an element of the obscene, but the normal definition of 'indecent' merely refers to nonconformance with accepted standards of morality." Id. at 740.

122 Community Television of Utah, 611 F. Supp. at 1105.

$123 \mathrm{Id}$. The court ultimately found that regulation of indecent cable programming was constitutionally prohibited. Id. at 1116-17.

124 See, e.g., Capital Cities Cable, Inc. v. Crisp, 467 U.S. 691 (1984) (federal preemption of a state ban on liquor advertisements on cable upheld under the 1934 Communications Act). 
information sources and services to the public." 125

\section{Judicial Analysis of Specific Cable Act Sections}

\section{A. Rate Regulation}

One of the major changes created by the Cable Act was the deregulation of subscriber rates for "basic cable service" in franchise areas where the cable system was "subject to effective competition."126 The FCC was given authority to define such "effective competition," and, after a two year transition period, ${ }^{127}$ franchising authorities have only been permitted to regulate subscriber rates for basic cable service in those localities which meet the FCC's definition. In other communities, cable operators have been free to increase rates at their own discretion.

The FCC defined "effective competition" for a cable system as occurring when at least three local over-the-air broadcast television signals were available in a community. ${ }^{128}$ A signal was defined as being available if it placed a "predicted Grade B contour" over any part of that community or if the signal was "significantly viewed."

On appeal, the FCC's determination that three broadcast signals created "effective competition" for a cable system was upheld. ${ }^{130}$ The court, however, concluded that the definition of "availability" as including a signal that theoretically might cover "any" part, no matter how slight, of a community created an "enormous margin of error" for determining actual availability of signals. ${ }^{131}$ The court remanded this part of the rulemaking back to the FCC for further examination.

The court also rejected the FCC's determination that in those communities where rate regulation of "basic cable service" would be permitted, regulation would be permitted for only one

125 Cable Act $\S 601(4), 47$ U.S.C. $\$ 521$ (4) (Supp. III 1985).

126 Cable Act $\$ 623(\mathrm{~b}), 47$ U.S.C. $\$ 543$ (b) (Supp. III 1985).

127 The transition period ended December 29, 1986 for cable systems franchised before the October 30, 1984 enactment of the Cable Act. See Cable Act $\$ 9,47$ U.S.C. $\S 521$ (Supp. III 1985). Franchises awarded after October 30, 1984 were not under the transition rules, but controlled by the FCC's definition of "effective competition" from the date it was released, April 19, 1985. Implementation, supra note 10, at 18,648.

128 See Implementation, supra note 10, at 18,648-50.

129 Id. at 18,650-51. A "predicted Grade B contour" is an estimate of the strength of a broadcast signal. See 47 C.F.R. \& 73.683(a) (1985). The estimate does not factor in local topographical features, such as mountains, that might interfere with signal reception, nor does it guarantee that the picture transmitted will be of acceptable quality. The FCC decides, based upon percentage of viewership, which channels would be considered "significantly viewed." See 47 C.F.R. $\$ 76.54$ (1985).

130 ACLU v. FCC, 823 F.2d 1554 (D.C. Cir. 1987).

131 Id. at 1573 . 
tier of service that provided service to all subscribers. ${ }^{132}$ In holding that the FCC was bound by the Act's broader definition of "basic cable service," 133 the court rejected a statement in the legislative history to the Act that the FCC was free to establish its own definition of "basic cable service." The legislative history stated that the Act's definition was only for the two year transition period and that the FCC had "flexibility" in determining its definition of "basic cable service." 134 The court rejected this use of the legislative history because on the matter of defining "basic cable service," the Act speaks "with crystalline clarity."135 Since the Act itself did not contain any limitation on its definition, the FCC did not have the flexibility envisioned in the legislative history.

While most of the legal battles over rate regulation involved the FCC's definition of "effective competition," 136 several courts have dealt with rate regulation issues outside of the FCC's jurisdiction. Although these cases involve issues that arose during the transition period, many of these issues will be relevant to those franchises that will continue to be rate-regulated due to a lack of "effective competition."

In Village of Schaumburg $v$. Cablenet, Inc. ${ }^{137}$ a cable operator increased subscriber rates over one hundred percent. ${ }^{138}$ The Village objected on two grounds: 1) the cable company had not given the 180-day notice of rate increase required by the Cable Act; ${ }^{139}$ and 2) the operator had increased rates more than the five percent allowed by the Act. ${ }^{140}$

Before reaching the substance of the Village's complaint, the court had to rule on the meaning of the word "franchise." Section $623(\mathrm{c})$ permitted rate regulation during the transition period, "to the extent provided in a franchise." 141 The franchise

\footnotetext{
132 See Implementation, supra note 10 , at 18,653 .

133 Cable Act $\$ 602(2), 47$ U.S.C. $\$ 522(2)$ (Supp. III 1985), defines "basic cable service" as "any service tier which includes the retransmission of local television broadcast signals." (emphasis added).

134 HOUSE REPORT, supra note 8, at 66.

135 ACLU, 823 F.2d at 1568.

136 See supra text accompanying notes 127-79.

137 Village of Schaumburg v. Cablenet, Inc., No. 86-C-1710, slip op. (N.D. Ill. July 31, 1986) (LEXIS, Genfed library, Dist file).

138 The monthly charge for basic service increased from $\$ 6.25$ to $\$ 12.95$. Id. at screen 5.

139 See infra note 147.

140) See infra note 149.

141 Cable Act $\S 623(\mathrm{c}), 47$ U.S.C. $\S 543$ (c) (Supp. III 1985) (emphasis added). Similarly, section $623(\mathrm{e}), 47$ U.S.C. $\$ 543(\mathrm{e})$ (Supp. III 1985) permits a cable operator to increase rates five percent a year if the "franchise" does not specify a fixed rate. See infra text accompanying note 149.
} 
before the court, however, did not contain the specific provisions governing local regulation of rates; those details were contained in a local ordinance which was referred to in the franchise. ${ }^{142}$ The court ruled that the existence of rate regulation power in the ordinance was sufficient to meet the statutory definition. ${ }^{143}$ This holding reflects both the purpose behind the statutory language, which merely required that the cable operator be subject to rate regulation prior to the enactment of the Cable Act, and the broad statutory definiton of "franchise." 144

Despite the holding that rate regulation was permitted, the court concluded that the rate increase was valid. ${ }^{145}$ Even though the Cable Act provides for a 180-day waiting period following a request for a rate increase so that a franchising authority can decide whether to veto such an increase, ${ }^{146}$ the court held that this period could be shortened by the franchise. ${ }^{147}$ Since the franchise only required ninety days notice and the cable operator had met that limit, the court held that the time requirement had been fulfilled. ${ }^{148}$

Similarly, the court held that the automatic five percent per year rise in subscriber rates permitted in the $\mathrm{Act}^{149}$ could be increased by the franchise. Moreover, if the franchise did not itself

142 The franchise stated that the cable operator accepted all obligations imposed by the ordinance, "to the same degree and extent as if each and every such provision were repeated." Village of Schaumburg, at screen 3.

143 Id.

144 According to the Cable Act, "franchise" encompasses any authorization for the operation of a cable system, "whether such authorization is designated as a franchise, permit, license, resolution, contract, certificate, agreement, or otherwise." Cable Act $\S 602(8), 47$ U.S.C. $\$ 522(8)$ (Supp. III 1985); see Housatonic Cable Vision Co. v. Department of Pub. Util. Control, 622 F. Supp. 798, 810 (D. Conn. 1985) (The word "franchise" is "broad enough to encompass the wide variety of methods whereby localities regulated cable systems prior to the Cable Act."); American Television \& Communications Corp. v. City of Montevideo, 603 F. Supp. 1376, 1378 (D. Minn. 1985) (unilaterally enacted "resolution" by city is within definition of "franchise"); see also supra text accompanying notes 127-79.

145 Village of Schaumburg, at screen 16.

146 Cable Act $\$ 623$ (d), 47 U.S.C. $\$ 543$ (d) (Supp. III 1985). This request is for an increase above the five percent automatic increase. See supra text accompanying notes 127-79.

147 Village of Schaumburg, at screen 16.

148 Id. at screen 16.

149 Cable Act $\$ 623(\mathrm{e})(1), 47$ U.S.C. $\$ 543(\mathrm{e})(1)$ (Supp. III 1985). One court has ruled that the statutory language permitting a five percent increase "per year," permits the increase each calendar year, rather than after a twelve month period dating from an increase. Town of Barnstable v. TCI-Taft Cablevision Assoc., No. 86-0143, (D. Mass. May 13, 1986) (LEXIS, Genfed library, Dist file). The automatic increase is available unless a franchise, in existence on the effective date of the Cable Act (Dec. 29, 1984), specifies "a fixed rate or rates for basic cable service for a specified period or periods which would be exceeded if such increase took effect." Cable Act $\$ 623(\mathrm{e})(1), 47$ U.S.C. $\$ 543(\mathrm{e})(1)$ (Supp. III 1985). A franchise that establishes a particular rate does not specify a "fixed" rate if it permits the rate to be increased with the approval of the franchis- 
limit the increase, the cable operator would be free to raise rates by more than five percent. ${ }^{150}$ Although the ordinance in Schaumburg only gave the Village the power to reject a proposed increase by holding a hearing, no hearing was held. The court concluded that since nothing in the franchise prevented the doubling of subscriber rates, the increase was permissible under the Cable Act. ${ }^{151}$

The court's logic in Schaumburg was the same for both of these provisions; the Cable Act rate regulation provisions were not intended to add any burdens to the cable operator. According to the court, "Congress did not intend to place restrictions where none existed .... There is no basis to believe that in a case such as this, limitations were intended to be imposed which were not otherwise established by ordinance or contract." 152

It is not at all clear, however, that the same principle should apply to both the five percent increase and the 180-day provisions. In providing for the automatic rate increase, Congress explicitly stated that the increase was "[i]n addition to any other rate increase which is subject to the approval of a franchising authority." 153 Thus, Congress envisioned that a franchise might well permit additional rate increases. ${ }^{154}$

In contrast, the Cable Act states that a franchising authority has 180 days to render a decision on a request for a rate increase, "unless the 180-day period is extended by mutual agreement of the cable operator and the franchising authority." 155 There is nothing in the statutory language that permits the time period to be reduced by mutual agreement. Congress apparently felt that since the cable operator was permitted to raise rates by five percent without notice or local approval, franchising authorities should be given sufficient time to act on additional increases. Congress also determined that 180 days was an appropriate time. ${ }^{156}$ Ac-

ing authority. American Television \& Communications Corp. v. City of Montevideo, 603 F. Supp. at 1379.

150 Cable Act $\S 623(e)(2), 47$ U.S.C. $\$ 543(\mathrm{e})(2)$ (Supp. III 1985).

151 Village of Schaumburg, at screen 16.

152 Id. at screen 17.

153 Cable Act $\S 623(\mathrm{e})(1), 47$ U.S.C. $\S 543(\mathrm{e})(1)$ (Supp. III 1985).

154 The legislative history also indicates that the five percent increase could be expanded by the franchise; "This automatic increase is not meant to be a ceiling on rates. .. . [Congress] intends that the automatic increase ... shall be available in addition to any other increase procedure that may be established by a franchise." House REPORT, supra note 8 , at 67-68.

155 Cable Act \$ 623(d), 47 U.S.C. \$ 543(d) (Supp. III 1985) (emphasis added).

156 The legislative history also implies no power to shorten the 180-day limit. See HOUSE REPORT, supra note 8, at 67 ("[S]ubsection 623(d) requires that a franchising 
cordingly, the Schaumburg court may have incorrectly permitted a shorter time period than that required by the Cable Act.

An issue involving rate regulation that may have significant ramifications for the future is the meaning of the word "rates." Congress has preempted local regulation of "the rates for the provision of cable service," except for basic service of those cable operators not facing "effective competition." 157 "Cable service" is defined as consisting of "video programming or other programming service together with subscriber interaction, if any, which is required for the selection of such programming." 158 Congress, however, did not define either what is meant by "the provision of cable service" or even the word "rates." One court which has addressed this question thus far has ruled that the scope of the federal limit on local regulation of "rates" can only be understood in the context of the other provisions of the Cable Act affecting local regulatory power. ${ }^{159}$

In Housatonic Cable Vision, ${ }^{160}$ the court upheld a state prohibition on a cable company charging subscribers who reside in sparsely populated areas as "contribut[or]s in aid of construction." 161 The court ruled that such contributions "are not rates for the provision of cable service within the meaning of the Act, and that the Cable Act does not preempt franchising authorities from making decisions concerning such contributions." 162

What makes this decision significant beyond the question of line extension regulation is the reasoning of the court. The court based its determination on the fact that a separate section of the Act required franchising authorities to assure that access to cable service not be denied to any group of potential subscribers because of the income of those who reside in their neighborhood. ${ }^{163}$ The court concluded that "[d]enying franchising authorities the power to prohibit contributions in aid" of con-

authority act within 180 days . . . unless the 180-day period is extended by mutual consent.").

157 Cable Act $\$ 623$ (a), (b)(1), 47 U.S.C. $\$ 543(a)$, (b)(1) (Supp. III 1985).

$15 \AA$ House REPORT, supra note 8 , at 41 ; see Cable Act $\$ 602(5), 47$ U.S.C. $\S 522(5)$ (Supp. III 1985).

159 Housatonic Cable Vision Co. v. Department of Pub. Util. Control, 622 F. Supp. 798, 808 (D. Conn. 1985).

160 Id. at 798 .

161 Id. at 802 . The court also upheld a requirement that a cable company should wire sparsely populated areas, (i.e., areas with fewer than 25 prospective subscribers), as within the local government's statutory power. Id. at 807 (citing Cable Act $\$ \S 624$ (b), 624(c), 632(a), 47 U.S.C. $\S \S 544(\mathrm{~b}), 544(\mathrm{c}), 522$ (a) (Supp. III 1985)).

162 Housatonic Cable Vision, 622 F. Supp. at 808.

163 Cable Act $\S 621$ (a)(3), 47 U.S.C. $\$ 541$ (a)(3) (Supp. III 1985). 
struction would be in "direct conflict" with this requirement. ${ }^{164}$ The conflict would apparently arise since such charges would single out one group to pay more for cable service, thereby contradicting the congressional "emphasis on encouraging equal access to cable television." 165 The court concluded that it would not define the ambiguous phrase "rates for the provision of cable service" so as to conflict with unambiguous provisions of the same statute. Therefore, contributions in aid of construction may still be subject to local regulation. ${ }^{166}$

Applying this reasoning, certain other charges by a cable operator may also be subject to local regulation. For example, the Cable Act requires every cable operator to sell or lease devices called "lock boxes" at their subscribers' requests. These devices permit subscribers to block the reception of certain channels on their television sets ${ }^{167}$ for the purpose of allowing subscribers to keep obscene and indecent programming out of their homes and away from their children. ${ }^{168}$ Just as Congress stressed the importance of equal access to cable television, it also stressed the importance of making lock boxes available to all who wished to keep "objectionable" programming out of their homes. ${ }^{169}$

Lock boxes are similar to line extension and do not fit into the definition of "cable service" as video programming. ${ }^{170}$ As with the prohibition on contributions in aid of construction, if local governments wish to regulate the price of lock boxes so as to ensure their maximum availability, a ban on such regulation would "defeat express provisions of the same statute."171

Similarly, franchising authorities may be able to regulate the price subscribers must pay in order to receive access programming. Access programming is programming by third parties

164 Housatonic Cable Vision, 622 F. Supp. at 808.

165 Id. at 811 . Congress stated that one purpose of the Cable Act was to require that "cable service be made available in all areas of a city, so that residents of lower income areas are not deprived of cable service." HousE REPORT, supra note 8, at 20.

166) The court also noted that if contributions in aid of construction were considered part of the rates for cable service, such contributions would be barred by Cable Act $\S 623($ ()(1), 47 U.S.C. $\S 543(f)(1)$ (Supp. III 1985) which permits both federal and local authorities to "prohibit discrimination among customers of basic cable service." Housatonic Cable Vision, 622 F. Supp. at 808 (quoting 47 U.S.C. $\$ 543(\mathrm{e}) \&(\mathrm{f})$ ).

167 Cable Act $\S 624$ (d)(2)(a), 47 U.S.C. $\$ 544$ (d)(2)(a) (Supp. III 1985).

I is See House REPORT, supra note 8, at 70; see supra notes 115-25 and accompanying text.

169 Congress stated that it was "extremely concerned with the dissemination of programming containing explicit sexual material which might be offensive to many cable subscribers [and] particularly concerned about the availability of such programming to child viewers." House RePORT, supra note 8, at 69.

170 See supra notes 161-66.

171 Housatonic Cable Vision, 622 F. Supp. at 808. 
other than the cable operators and the programmers they select. The Cable Act "grants franchising authorities explicit authority to establish requirements for the designation and use of public, educational and governmental ("PEG") access channels."172 These channels were considered by Congress to "serve a most significant and compelling governmental interest-promotion of the basic underlying values of the First Amendment itself." 173

Significantly, franchising authorities are empowered not only to require that channels be set aside for PEG access programming, but to "require rules and procedures for the use of the channel[s]."174 Therefore, a rule promulgated under this section which governs the price consumers are charged to receive PEG access channels would not be preempted by the Cable Act's limitation of rate regulation under the reasoning of Housatonic Cable Vision. Preemption, if permitted, would conflict with the explicit statutory goal of utilizing PEG access to create a "wide diversity of information sources for the public"175 and "contribute to an informed citizenry." ${ }^{176}$ Moreover, it may well be that fees charged by a cable operator for viewing PEG channels are not "rates for the provision of cable service"177 since the cable operator does not "provide" PEG access programming. Access programming is "provided" by the individual access programmer; cable operators merely act as "conduits" with no editorial discretion. ${ }^{178}$ A perfectly consistent way to balance the competing purposes of the Cable Act would be to hold that rates for that programming controlled or selected by the cable operator are unregulated. The price charged for third party access programming is regulated to ensure, in the words of one legislator, "that local community needs for public, educational, and governmental programming are met." 179

172 House Report, supra note 8, at 45; see Cable Act $\$ 611,47$ U.S.C. $\$ 531$ (Supp. III 1985).

173 House Report, supra note 8, at 34. "The goal of the First Amendment is to 'foster' the widest possible dissemination of information from diverse and antagonistic sources." Id. at 31 (quoting Associated Press v. United States, 326 U.S. 1, 20 (1945)).

174 Cable Act $\$ 624$ (b), 47 U.S.C. $\$ 544$ (b) (Supp. III 1985).

175 House RePORT, supra note 8, at 30.

176 Id.

177 Cable Act \& 623(a), 47 U.S.C. § 543(a) (Supp. III 1985) (emphasis added).

178 HOUSE REPORT, supra note 8 , at 35 .

179130 Conc. Rec. H10,440 (daily ed. Oct. 1, 1984) (Remarks of Rep. Rinaldo). Rep. Rinaldo continued: "This form of programming is extraordinarily important to the citizens in the communities that are served by cable, and it promises to bring with it a more enlightened and better informed citizenry in the years to follow." Id.; see also 130 ConG. REC. H10,444 (daily ed. Oct. 1, 1984) (remarks of Rep. Bryant) ("[C]onsumers and viewers benefit greatly from [the Cable Act] because public, governmental, and educational access is guaranteed so the needs of the community can be met."). 


\section{B. Modification}

Prior to the Cable Act, many companies sought to reduce the commitments they had made in their franchises with local governments:

[I]n many cities around the country, in the period before passage of the Act, cable companies sought to be excused from the performance of obligations under their franchise agreements, obligations which they found too onerous or too costly. In many of these communities, the franchising authority took the position that a cable operator ought to be held to its promises. ${ }^{180}$

Congress, in recognition of these disputes, ${ }^{181}$ created a mechanism whereby a cable operator could force a franchising authority to modify franchise commitments. ${ }^{182}$ In order to be relieved of a franchise requirement for provision of facilities and equipment, the operator must demonstrate that the requirement is "commercially impracticable." 183 This phrase, taken from the Uniform Commercial Code, ${ }^{184}$ sets a difficult standard for modifying a promise made by the cable operator since: there must have been a change in circumstances; the change must have been unforeseen and unforeseeable by the cable operator and beyond the operator's control; and this change must alter a basic assumption on which the franchise was originally based, beyond simply lowering revenue or raising expenses. ${ }^{185}$

While the precise circumstances necessary to establish "commercial impracticability" have not yet been judicially determined, some important preliminary questions have been faced. In MatrixVision of Wilmette, Inc. $v$. Village of Wilmette, ${ }^{186}$ the court ruled that the

180 D. Brenner \& M. Price, Cable Television and Other Nonbroadcast Video: LaW and Policy 3-38 (1986).

181 See House REPORT, supra note 8, at 22 ("The result of the renegotiation process has been to create very contentious relationships between franchising authorities and cable operators and artificially inflate expectations among consumers.").

182 Cable Act $\$ 625,47$ U.S.C. $\$ 545$ (Supp. III 1985). The franchising authority and the cable operator remain free to modify the franchise on their own, outside of the procedures of the Cable Act. House RePort, supra note 8, at 71 .

183 Cable Act $\$ 625$ (a)(1)(A), 47 U.S.C. $\$ 545$ (a)(1)(A) (Supp. III 1985).

184 " 'Commercial impracticability' is defined as it is in the Uniform Commercial Code, $\S 2-615$. It is intended that this standard will be applied to cable operators' proposals for modification in the same manner that the UCC applies-recognizing that courts may need to make distinctions given the difference between the context in which it is applied here and that regarding the sale of goods which is governed by the UCC." HOUSE REPORT, supra note 8 , at 71 .

185 See generally Meyerson, The Cable Communications Policy Act of 1984: A Balancing Act on the Coaxial Wires, 19 GA. L. REv. 543, 573-76 (1985).

186 No. 85-C-5784 (N.D. Ill. Oct. 24, 1985) (LEXIS, Genfed library, Dist file). 
Cable Act does not require a formal request by the operator for a modification. In MatrixVision, the operator's request to modify a franchise requirement to construct a second, so-called, "shadowtrunk" cable was made at a Village hearing held to determine why the operator should not be penalized for failing to meet this obligation. ${ }^{187}$ The court held that the Act imposed no requirements "as to the context in which such a request for modification is to be made."188 Rather than "prescribe rigid procedural requirements," 189 Congress only required that a "request" of some kind be made. ${ }^{190}$ While this holding is essentially correct, in the interest of fairness it seems clear that however the "request" is made, the operator must inform the franchising authority that the "request" is different from the normal ongoing discussions between contracting parties and that denial of the request could lead to court appeal.

The court also held that this "request" need not allege, let alone show, that the existing franchise requirements are commercially impracticable; ${ }^{191}$ that determination is left solely for the reviewing courts. There is, however, language to the contrary in the legislative history. That language seems to indicate that an operator, in order to take advantage of the statutorily imposed modification procedure, must first give the franchising authority the opportunity to determine, for itself, whether a requirement is commercially impracticable. "Under subsections 625 (a) and (b), the cable operator may obtain modification of a requirement for facilities and equipment if it can show, in negotiations with the franchise authority or in court if an action is taken, that the existing contract requirement is 'commercially impracticable." "192

Irrespective of section 625 , the franchising authority retains the power to grant a modification whenever it decides such modification is appropriate, even without a showing of commercial impracticabil-

187 Id. at screen 3 . The "request" may only have been an oral request; there is no reference in the case to any written request for modification.

188 Id. at screen 7.

189 Id.

$190 \mathrm{Id}$. The court incorrectly relied on the statement in the legislative history that the “procedures established under [Cable Act $\$ 625$ ] are intended to supplement, and not replace, other procedures available for modification" to prove that Congress did not intend to impose specific procedural requirements. Id. (quoting HousE REPORT, supra note 8, at 71). Even though Congress intended to permit cities and cable operators to devise their own procedures for modification, Congress did not intend to include procedural safeguards in the mandatory statutory procedure. The question will be, therefore, whether there is any indication that Congress felt that certain safeguards, such as the 120 days for governmental action on the request, Cable Act $\S 625$ (a)(2), were necessary to protect both parties.

191 Id. at screens 8-9.

192 House REPORT, supra note 8, at 71 (emphasis added). 
ity. Thus, the reference in the legislative history to requiring modifications if commerical impracticability is shown in "negotiations with the franchise authority," 193 implies an obligation to give the franchising authority the opportunity to decide if the statutory standard is met before the cable operator may ask a court to review that decision. This view is also consistent with the general principle of exhaustion of remedies, which requires that a local government be permitted to rule on an issue before appeal is taken to the federal courts. ${ }^{194}$ Since Congress requested that a franchising authority make a "final decision" before an appeal can be taken, ${ }^{195}$ it seems likely that Congress intended that the franchising authority be able to make its "final decision" after considering the same factors on which a court would eventually rule.

In the other major case on contract modification, Tribune-United Cable of Montgomery County v. Montgomery County, ${ }^{196}$ the Fourth Circuit held that a request for a modification "automatically stays any action on the part of the franchising authority to enforce the penalty provisions of the franchise agreement until its decision has been finalized." 197 The court stated that Congress had provided that an operator who proves "commercial impracticability" is "relieved $e n$ tirely from the adverse aspects of those portions of the agreement."198 Accordingly, the court held that the request for modification bars the imposition of penalties, not only for violations of the franchise after the request, but for those that preceded it as well. This bar is only to be lifted after the franchising authority has made its decision on the modification request. ${ }^{199}$

The problem with the court's analysis is that the Cable Act never states that the operator is to be "entirely" relieved of its contractual obligations. The court's analysis ignores the fundamental distinction in contract law between "existing impracticability," when the cause of the difficulty exists at the time the contract was signed, and "supervening impracticability," when the event occurs after the contract is signed. ${ }^{200}$ This distinction determines the scope of the

$193 I d$.

194 E.g., Cardinale v. Louisiana, 394 U.S. 437 (1969) (state courts must be given the opportunity to rule on federal constitutional issues before appeal to the Supreme Court).

195 Cable Act $\S 625$ (b)(1), 47 U.S.C. $\$ 545(b)(1)$ (Supp. III 1985).

196784 F.2d 1227 (4th Cir. 1986).

197 Id at 1231 . The court indicated that a "bad faith or frivolous application for modification" would not stay the penalty. Id.

198 Id. at 1230 (emphasis added).

199 The Tribune-United Cable court did not comment on whether the penalty must await judicial review of the franchising authority's determination.

200 E. Farnsworth, Contracts 696 (1982). 
relief available to the party unable to fulfill the contractual obligation. "The effect of supervening impracticability or frustration on the excused party is usually to discharge his remaining duties of performance. The effect of existing impracticability or frustration on the excused party is usually to prevent any duty of performance on his part from arising."201

Thus, the fact that an event has made performance of the contract as originally drafted impracticable does not protect the promisor from being in breach for contract violations that existed before the event occurred. The language of the modification provision of the Cable Act does not directly or implicitly reverse this black letter principle. At a minimum therefore, a franchising authority should retain the right to penalize the cable operator for any violation occuring before the alleged impracticability arose.

Moreover, if the operator is to be protected, at least temporarily, from penalty for its breaches of the franchise agreement, there must be a concomitant responsibility on the part of the cable operator to make the request for modification as soon as the impracticability becomes apparent. Otherwise, an operator could delay invoking the procedure right up to the time the franchising authority is ready to impose a penalty for the violation. For example, in Tribune-United Cable, the operator violated franchise provisions relating to wiring deadlines and to the construction of an Institutional Network ("I-Net") in addition to the subscriber cable. ${ }^{202}$ Subsequently, the franchising authority issued two formal notices of default. ${ }^{203}$ The second threatened "to invoke the penalty provisions of the franchise agreement." 204 On November 8, 1985, seven days after the second notice and two and one-half years after the franchise was signed, the cable operator "formally requested modification ... pursuant to section 545 of the [Cable Act]."205

The operator apparently made a deliberate decision not to comply with its franchise obligations. The court stated that the operator had, "decided not to construct the I-Net system . . . [and] ceased laying cable to new areas." ${ }^{206}$ At minimum, good faith

\footnotetext{
201 Id. at 698 .

202 Tribune-United Cable, 784 F.2d at 1228-29.

$203 \mathrm{ld}$. at 1229 . The county sent Tribune the first formal notice of default on September 19,1985 . The second notice was issued on November 1,1985 .

204 Id.

205 Id.

206 Id. Prior to the request for modification, the operator did question "the economic feasibility of a number of franchise requirements" and "informally [requested] a review of the franchise agreement." Id. It is apparent however, that no notice was given of the final decision by the operator to breach its promises until the requirements had been violated and the penalty imminent.
} 
should have required that notice be given to the franchising authority before the breach began. Such notice would give the county the opportunity to make alternate arrangements and possibly change the franchise to an intermediate requirement.

The Fourth Circuit stated that the imposition of the penalty should be stayed since, "[s]everely penalizing an embryonic cable operation which may be stymied by commercial impracticabilities before it has had an opportunity to take advantage of the federally mandated right to modification does not strike us as promoting the objectives of the Act." 207 This reasoning will not help a cable operator who delays significantly in requesting modification after problems have arisen. As soon as the difficulty becomes known, however, the operator has this opportunity "to take advantage of the ... right to modification." 208 A penalty imposed after a substantial delay in requesting a modification (and after a continuing violation of the franchise), therefore, would be imposed only after the operator had the opportunity to request the modification and thus would not interfere with the objectives of the Act.

Finally, it must be noted that the request for modification in this case occured before the penalty was imposed. Entirely different considerations would arise if the operator sought to be relieved of a penalty by requesting a modification after the penalty had been imposed. The court was concerned with cities placing a "burden" on the right to modify by imposing penalties. ${ }^{209}$ Obviously there is no such burden if a penalty for a franchise violation is imposed absent the request for modification. A subsequent request for modification should not affect the validity of a previously imposed and previously valid penalty.

\section{Tenants'Access to Cable Television}

The Cable Act supplements the cable operators' rights under a franchise by giving them the right to construct their cable systems "over public rights-of-way, and through easements .. . which have been dedicated for compatible uses." "210 Since this language specifically encompasses all easements granted to utilities, by private as well as by governmental entities, ${ }^{211}$ cable

\footnotetext{
207 Id. at 1231 (emphasis added).

208 Id.

200 Id.

210 Cable Act $\$ 621$ (a)(2), 47 U.S.C. $\$ 541$ (a)(2) (Supp. III 1985).

211 See generally HouSE REPORT, supra note 8, at 59 ("Any private arrangements which seek to restrict a cable system's use of such easements or rights-of-way which have been granted to other utilities are in violation of this section and not enforceable.").
} 
operators have sought to use this section to require landlords to permit the franchised cable operator to offer service to tenants.

In the two cases on this issue, Rollins Cablevue, Inc. v. Saienni Enterprises, ${ }^{212}$ and Greater Worcester Cablevision, Inc. v. Carabetta Enterprises, Inc. ${ }^{213}$ the courts found that the Cable Act does grant cable operators the right to enter private multiple dwellings through easements. The difference in the two cases is that in Greater Worcester, the court found that the cable operator would be unable to offer service to tenants "using only existing utility easements and public rights-of-way."214 Accordingly, the court ruled that the Cable Act did not give the operator the right to use the landlord's property to offer service. ${ }^{215}$

By contrast, the Rollins court decided that cable operators would be permitted to wire the apartment buildings, since the apartments were "served by electric, telephone and, most probably, water and sewer easements." 216 While neither court describes in adequate detail the factual basis for its conclusions, the latter approach seems to be more consistent with the legislative goal to "insure that the public receives the widest possible diversity of information services and sources." 217 Therefore, the question should not be whether a "complete" cable system can be constructed through easements, but whether the easements will lead into individual apartments. ${ }^{218}$ If they do, the operator should be permitted to provide service to any tenant who wishes to pay for it. The resulting wiring would run from the public rights-of-way in the street, through the easement, and into the apartment of the tenant who desires cable service. No legitimate interest of the landlord would be implicated, and the cable wiring in the apartment could be removed if the next tenant in the apartment did not want the service.

212633 F. Supp. 1315, 1322 (D. Del. 1986).

213 No. 85-2022, slip op. (D. Mass. Nov. 20, 1985) (LEXIS, Genfed library, Dist file).

214 Id. at screen 42.

215 Id. at screens $42-43$.

216 Rollins Cablevue, 633 F. Supp. at 1322.

217 Id. at 1318 (citations omitted).

218 The landlord in Greater Worcester contended, "as a factual matter, that the utility easements [did] not extend into each apartment; at some point in order to wire [the apartment complex, the cable operator's] equipment will leave the easements and pass onto [the landlord's] property." Greater Worcester, slip op. at screen 40 . While the court gives no further details about the property, and ultimately concludes that the landlord was correct, it is unclear how each tenant was provided with "telephone service, natural gas and electricity," id. at screen 38, without the various easements running directly into the individual apartments. Either the buildings in the case were of unusual design or the court misunderstood both the nature of the easements and the rights under the Cable Act. 
Both courts seemed to agree that state laws granting similar or greater access for cable operators to apartment buildings were not preempted by section 621 . The Rollins court, in fact, used the access laws of the State of Delaware to aid in interpreting the Cable Act's requirements. ${ }^{219}$

The Greater Worcester court found the Massachusetts access statute unconstitutional, not because of preemption but because it did not provide compensation for the "taking" of the landlord's property by the cable operator. ${ }^{220}$ This interpretation of the state law is questionable, however, since the court also found that the federal access provisions did meet the standards of due process by requiring that property owners be fully compensated for whatever takings might occur from the installation of cable facilities. ${ }^{221}$ The court did not explore whether the federal provisions would provide a landlord adequate compensation for damages "caused by the installation, construction, operation, or removal of ... [facilities necessary for a cable system] by the cable operator," 222 who obtains access under both the federal and state access provisions. If such compensation would be available and sufficient, the Cable Act would, in effect, provide the "just compensation" required by the fourteenth amendment, ${ }^{223}$ for the state statute's "taking."

\section{Cable Piracy}

The Cable Act contains two sections dealing with cable piracy: section 633, which prohibits unauthorized reception of "service offered over a cable system" 224 and section 605 , which prohibits unauthorized reception of radio signals. ${ }^{225}$ Section 633 is intended to cover theft from the cable system itself, while section 605 covers reception of signals transmitted through the

219 Rollins Cablerue, 633 F. Supp. at 1321 . "In resolving the question of the right of access, the law of the state in which the cable system is located may be significant." Id. The Cable Act, however, does not depend on local laws to govern the use of easements. While the Delaware statute led to substantially the same result as the Cable Act, the provisions of the Act will have the same meaning even in states lacking a similar law.

220 Greater Worcester Cablevision, at screens 13, 16, 18.

221 Id. at screen 41.

222 Cable Act $\S 621$ (a)(2)(C), 47 U.S.C. $\$ 541$ (a)(2)(C) (Supp. III 1985).

223 " $[\mathrm{N}]$ or shall any. State deprive any person of life, liberty, or property, without due process of law ...." U.S. ConST. amend. XIV, \& 1 .

224 Cable Act $\$ 633(\mathrm{a})(1), 47$ U.S.C. $\$ 553(\mathrm{a})(1)$ (Supp. III 1985).

225 Section 5 of the Cable Act amended the former section 605 of the Communications Act of 1934 (dealing with unauthorized reception of radio communications) and section 6 of the Cable Act redesignated it section 705. Nonetheless, the section was codified at 47 U.S.C. $\$ 605$ (Supp. III 1985). Accordingly, it will be referred to in this article as section 605 . 
air. ${ }^{226}$ One major difference between the two sections is that piracy from a cable system for private home use is barred by section 633, but the Cable Act exempts from liability the reception of over-the-air signals, through home satellite dish antennae, for noncommercial private viewing. ${ }^{227}$

The major issue that has been litigated in respect to both sections is the intent necessary to establish a violation. In Shenango Cable TV, Inc. $v$. Tandy Corp. ${ }^{228}$ a cable company sued the parent corporation of Radio Shack for selling a converter which enabled subscribers who received the least expensive tier of cable service to receive the programming of a more expensive tier without paying the cable company an additional fee. ${ }^{229}$ The court ruled that Radio Shack had not violated section 633 because the converter was designed and advertised to perform two legitimate functions: 1) permitting the use of remote channel control; and 2) permitting recording of one cable channel on a video casette recorder during the viewing of a different channel. ${ }^{230}$

According to the court, under section 633, a manufacturer, distributor, or retailer of equipment "is liable only if he intends that the equipment he produces and sells be used for the interception or pirating of cable signals and the equipment is designed solely and specifically for that purpose."231 Because it was "unquestionably clear" that Radio Shack's converter is "not a pirating device designed and/or manufactured to assist a user

226 The legislative history indicates a congressional intent:

To limit the applicability of [Cable Act $\$ 633$ ] to theft of a service from the point at which it is actually being distributed over a cable system. Thus, situations arising with respect to the reception of services which are transmitted over-the-air (or through another technology), but which are also distributed over a cable system, continue to be subject to resolution under section 605 to the extent reception or interception occurs prior to or not in connection with, distribution of the service over a cable system.

HOUSE REPORT supra note 8 , at 83.

227 Cable Act $\S 605$ (b), 47 U.S.C. $\$ 605$ (b) (Supp. III 1985). Unauthorized home reception is only prohibited if the programming is scrambled or otherwise encrypted, or if there is an established marketing system for a particular programming service. Id. at $\S 605$ (b)(1),(2), 47 U.S.C. $\$ 605$ (b)(1),(2) (Supp. III 1985).

228631 F. Supp. 835 (W.D. Pa. 1986).

$229 I d$. at 836 . The lowest tier, costing $\$ 8.95$ a month, offered six to eight channels of cable programming. The next tier, costing an additional $\$ 2.75$ a month, offered another 12 channels. Id. at $836 \mathrm{nn} .3-4$.

230 Id. at 839.

231 Id. at 838 (emphasis in original). This is consistent with the legislative history that indicates that distributors, manufacturers and retailers should not be held liable for equipment, "which is used for legal purposes merely because the same device or equipment is capable of being used for unauthorized reception of cable service, if they do not provide the equipment with the intent or specific knowledge that it will be used for the unauthorized reception of cable service." HOUSE REPORT, supra note 8, at 84. 
to 'tap' into",232 the cable system, there was no violation of section $633 .^{233}$

A similar lack of intent to violate the Cable Act protected a distributor of home earth station satellite dish antennae in Air Capital Cablevision, Inc. v. Starlink Communications Group, Inc. ${ }^{234}$ In Air Capital, the court ruled that section 605, "imposes no duty upon [a seller of dish antennae] to advise its customers about authorized or unauthorized use of the equipment."235 A customer's illegal reception of certain signals would only be attributed to a seller or manufacturer of the satellite dish who "willfully assists in the violation.",236

Such a willful intent to assist in the violation of the Cable Act was found in Storer Communications, Inc. v. Mogel. ${ }^{237}$ There, the defendants not only sold equipment capable of receiving cable service but "made clear ... that the purpose of purchasing their cable equipment was to enable the purchaser to avoid payment for the cable services received, [and] advised [their] customers on ways to ensure that the cable operator did not discover the unauthorized reception of cable services." 238 The court concluded without apparent difficulty that the defendants possessed the requisite intent to assist others in violating the Cable Act and that their sale of the equipment violated section $633 .{ }^{239}$

Similarly, a group of hotels and motels were found to have violated section 605 by installing satellite antennae to receive programming and retransmit it to their guests' rooms. ${ }^{240} \mathrm{Sec}-$ tion 605 exempts from liability, "receipt . . . of any satellite cable programming for private viewing." 241 Even though the viewing by hotel and motel guests was arguably "private viewing," the court correctly pointed out that the reception of programming by

232 Shenango, 631 F. Supp. at 840.

233 Id.

234601 F. Supp. 1568 (D. Kan. 1985).

235 Id. at 1572. The court also ruled that a cable company lacks standing to sue for unauthorized reception of a satellite signal. Id. Contra American Televison and Communications Corp. v. Floken, Ltd., 629 F. Supp. 1462, 1472 (M.D. Fla. 1986).

236601 F. Supp. at 1572. The court also quoted comments of Senator Goldwater: "These business persons would have to knowingly and willfully assist in enabling a particular individual to violate the law, not simply be aware that the equipment by itself or in combination with other components might possibly be used for prohibited purposes." Id. (quoting 130 Cong. Rec. S14,284 (daily ed. Oct. 11, 1984) (comments of Sen. Goldwater)) (emphasis omitted).

237625 F. Supp. 1194 (S.D. Fla.1985).

238 Id. at 1197.

239 Id. at 1198; Cable Act $\$ 633,47$ U.S.C. $\$ 553$ (Supp. III 1985).

240 American Television and Communications Corp. v. Floken, Ltd., 629 F. Supp. 1462, 1465 (M.D. Fla 1986).

241 Cable.Act $\S 605,47$ U.S.C. $\$ 605$ (b) (Supp. III 1985). 
hotels and motels was for "their own commerical advantage.",242 Moreover, legislative history makes it abundantly clear that the exemption was only for home viewing. ${ }^{243}$

Thus, the courts have been able to draw workable distinctions between legal and illegal unauthorized reception. It is lawful to use a satellite dish for private home reception but not for exhibition to paying customers. It is lawful to sell equipment that permits unpaid access to cable service, but only if the equipment is designed for other legitimate uses and is truly marketed only for those lawful purposes.

\section{Conclusion}

In enacting the Cable Act, Congress attempted to "bring our outdated communications laws into the information age." 244 In its first major overhaul of the Communications Act of 1934, Congress established a "national framework and Federal standards for cable franchising." 245

The Cable Act strives for a difficult balance, minimizing "unnecessary regulation that would impose an undue economic burden on cable systems," ${ }^{246}$ while permitting regulation necessary to "assure that cable systems are responsive to the needs and interests of the local community." 247 The judiciary has been given the primary responsibility of supervising the regulatory players and of ensuring that the proper dose of regulation is administered.

This task is not an easy one. The Cable Act is labyrinthine: lengthy, prolix, and complicated. The courts will have to proceed carefully if Congress' full intent is to be realized.

242629 F. Supp. at 1469.

243 According to the Committee Report: "The term 'private viewing' is intended to describe a situation whereby an individual purchases or otherwise acquires satellite receiving equipment and uses such equipment to receive satellite cable programming which he views within his private dwelling place." 130 Conc. REC. S14,288 (daily ed. Oct. 11, 1984); see also 130 Cong. Rec. H10,446 (daily ed. Oct. 1, 1984) (comments of Rep. Rose: "Today, we come a long way by making it clear that the manufacture, sale, and home use of earth stations are legal activities."); 130 CoNG. REC. H10,446 (daily ed. Oct. 1, 1984) (comments of Rep. Tauzin: "the right to view satellite television programming in one's home or other dwelling place").

244130 Cong. Rec. H10,435 (daily ed. Oct. 1, 1984) (statement of Rep. Wirth).

245 House REPORT, supra note 8 , at 20.

246 Cable Act $\$ 601(6), 47$ U.S.C. $\$ 521(6)$ (Supp. III 1985).

247 Id. at $\$ 601(2), 47$ U.S.C. $\$ 521(2)$ (Supp. III 1985). 